\title{
Leaf and Soil Nutrient Relations of Elaeocarpus joga Merr. in Oceanic Island Calcareous Soils
}

\author{
Thomas E. Marler ${ }^{1}$ \\ Western Pacific Tropical Research Center, College of Natural and Applied \\ Sciences, University of Guam, Mangilao, GU 96923
}

\section{John H. Lawrence}

U.S. Department of Agriculture, Natural Resources Conservation Service, Barrigada, GU 96913

Additional index words. Elaeocarpus, leaf stoichiometry, limestone soils, nutrient limitation, soil nutrients

\begin{abstract}
The leaf nutrient status and stoichiometry of nitrogen (N), phosphorus (P), and potassium (K) were determined for Elaeocarpus joga trees in Guam's dominant calcareous soils to understand nutrient limitations in limestone soils of Oceania and contribute to global databases on leaf economic spectrum studies. Supplemental $\mathbf{N}, \mathbf{P}$, or $K$ was added to soils to determine plant growth and nutrient concentration responses. Leaf and soil quantifications of nutrients enabled multiple trait comparisons. Supplemental $N$ stimulated growth of young cultivated plants without affecting leaf $N$ concentrations. Supplemental $K$ increased leaf $K$ concentration but did not generate a growth response. Supplemental $P$ did not affect growth or leaf $P$ concentration. $N: P$, $N: K$, and $K: P$ were most influenced by $K$ additions. Leaf $N$ and $P$ concentrations of mature trees in unmanaged settings were similar to unfertilized young plants in the controlled study, but leaf $K$ concentration was greater in the mature trees. Leaf nutrient relations were not overtly related to soil nutrient relations for mature trees. Results indicate that $\mathbf{N}$ and $K$ are the limiting factors in calcareous soils of the Mariana Islands for this endemic tree species, age and size of trees do not greatly influence leaf nutrient content, and leaf stoichiometry is constrained and less variable than soil stoichiometry.
\end{abstract}

Studying the $\mathrm{N}, \mathrm{P}$, and $\mathrm{K}$ relations in terrestrial plant leaves can provide useful information about nutrient limitations in dominant soils and the interactions among species (Ågren, 2008; Sterner and Elser, 2002). Stoichiometry may be useful for interpretation, and is defined as the relationship between two constituents of the ionome or metabolome and expressed as a quotient. For example, numerous authors have employed robust data sets to suggest that quantifying variations in leaf $\mathrm{N}, \mathrm{P}$, and $\mathrm{K}$ may be highly informative. These studies collectively indicate that leaf $\mathrm{N}: \mathrm{P}$ above 16 suggests $\mathrm{P}$ limitation to plant biomass production, $\mathrm{N}: \mathrm{P}$ below 14 suggests $\mathrm{N}$ limitation, and $\mathrm{N}: \mathrm{K}$ above 2.1 or K:P below 3.4 indicate $\mathrm{K}$ limitation (Aerts and Chapin, 2000; Güsewell, 2004; Koerselman and Meuleman, 1996; OldeVenterink et al., 2003; Tessier and Raynal, 2003). Other reports illuminate the importance

Received for publication 16 June 2015. Accepted for publication 17 Sept. 2015.

This material is based on work that is supported by U.S. Department of Defense Agreement DAMD17-00-2-0021 and by the National Institute of Food and Agriculture, the U.S. Department of Agriculture McIntire Stennis project under 2013-32100-06057.

${ }^{1}$ Corresponding author. E-mail: tmarler@uguam. uog.edu. of $\mathrm{K}$ concentrations in developing an understanding of tree physiology, and how $\mathrm{N}: \mathrm{K}$ and $\mathrm{K}: \mathrm{P}$ correlate with climate gradients (Gotelli et al., 2008; Rivas-Ubach et al., 2012; Sardans et al., 2012). Continued research into these generalities may help to answer critical questions about nutrient limitations at the local scale, and enhance our understanding of relationships between stoichiometric shifts and environmental gradients on the global scale.

All natural and managed systems may not conform to the general expectations of nutrient stoichiometry in plant leaf tissue (Craine et al., 2008). Therefore, caution should be used before imposing sweeping interpretations of widespread plant leaf nutrient relations until those relationships have been sufficiently studied at the local level. Moreover, underrepresented geographic locations may provide useful local results to improve the global understanding of terrestrial plant nutrient limitations and function, which may improve interpretations of global integrations such as leaf economic spectrum dynamics (Donovan et al., 2011; Metali et al., 2012; Wright et al., 2004, 2005).

Recent developments have exposed the potential of how anthropogenic changes may be altering elemental cycling. The continuous increase in global populations and highly variable growth conditions brought about by climate change underscore a critical need to better understand the management of plant productivity (von Wirén, 2011). These global change factors also highlight the urgency
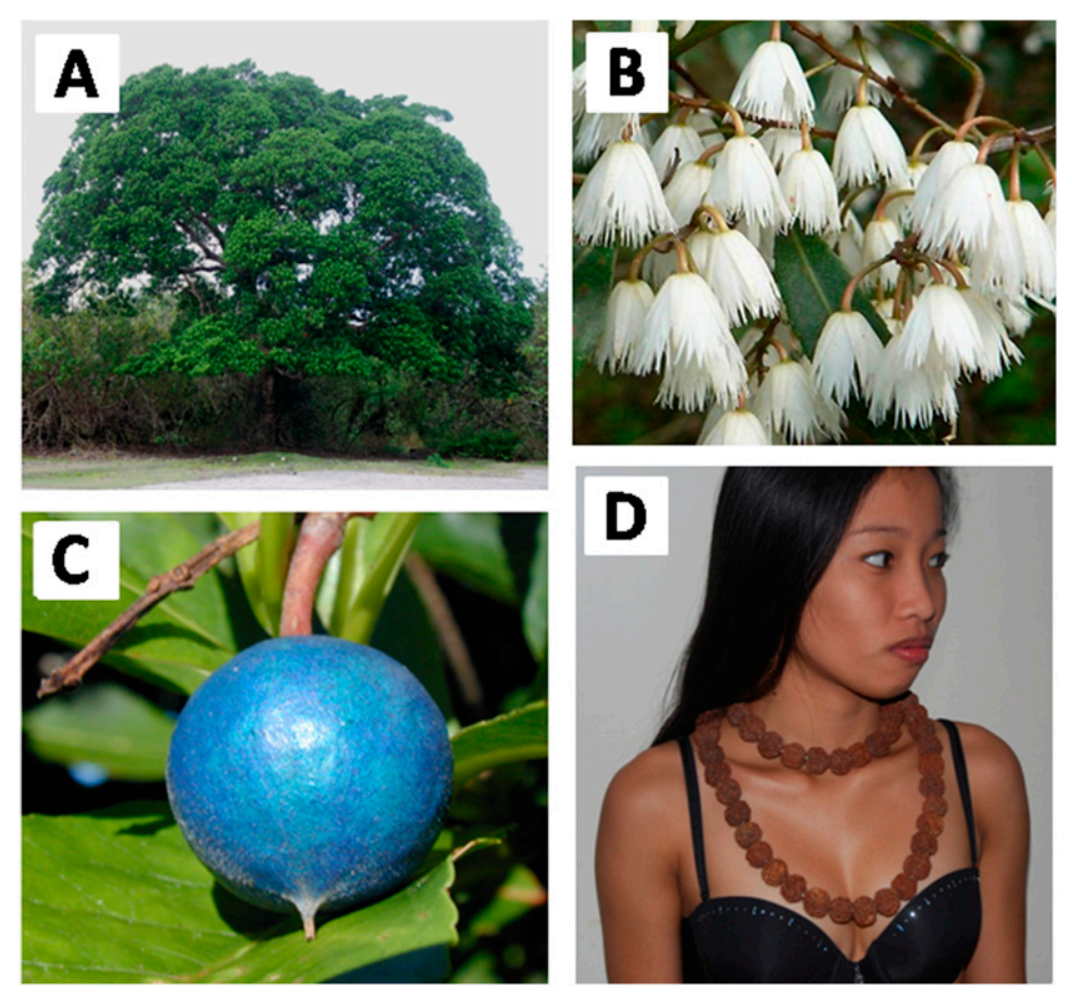

Fig. 1. Elaeocarpus joga trees possess highly distinctive traits. (A) The tree canopy is known for its unique architecture and foliage texture. (B) The distinctive flower corolla generates the nickname fairy petticoats. (C) Mature fruits are highly apparent in the canopy or on the forest floor after abscission because the exocarp transmits iridescent blue by light refraction rather than by pigmentation. (D) Cleaned endocarps are worn or held as beads by Hindu and Buddhist followers to provide myriad spiritual benefits. 
inadequately understanding and documenting the traits of highly managed systems, minimally managed agroforest systems, and natural ecosystems.

Guam is the southernmost island within the Mariana Island Archipelago and largest island within Micronesia. Two critical anthropogenic threats have emerged during the last quarter century to threaten native tree species. First, the proliferation of Boiga irregularis following its invasion during the late 1940 s by way of shipment of the U.S. military equipment (Rodda et al., 1992) resulted in extirpation of bird and bat species that has led to devastating impacts on the natural forest and agricultural ecosystems (Fritts and Rodda, 1998; Rogers et al., 2012). Second, the continued loss of vegetated habitats due to land conversion magnified pressures on the remaining fragmented habitats throughout the island. The amplified impact from multiple new alien arthropod species and an expansive military buildup will bring even greater need for understanding how to manage the urban forest (Marler, 2013a, 2013b; Marler and Moore, 2011).

Elaeocarpus joga is a distinctive member of the limestone forests of the Mariana Islands, and provides a striking canopy in the urban forest (Fig. 1). This and other members of the genus produce iridescent blue fruits, with ultrastructural light refraction generating the blue phenotype (Lee, 1991). Cleaned endocarps provide the resource for Rudraksha, which carries myriad medicinal and spiritual symbolisms in Hinduism and Buddhism (Seetha, 2008). This unique tree is one of the forest species that have become rare in recent decades due to habitat loss, increasing fragmentation, loss of avian seed dispersers, and impacts of alien ungulates (Raulerson and Rinehart, 1991). Leaf chemical traits of arborescent native forest species have not been studied for this portion of Oceania, so an understanding of nutrient cycling and stoichiometry for the region is lacking. A better understanding of the nutrient dynamics of tree species will benefit managers working to develop longrange management plans for this and other native forest trees (Wiles, 2005). We employed $E$. joga as a case study to begin developing an understanding of nutrient limitation and stoichiometry in the Mariana Islands. We used supplemental N, P, or K in a controlled system and the relationship between leaf and soil nutrient levels of unmanaged mature trees to meet this objective.

\section{Materials and Methods}

Fertilization study. Container-grown E. joga seedlings were employed to initiate a field study in Yigo, Guam. This field was characterized with Guam soil series, consisting of shallow cobbly clay loams that formed in sediments that overlie coralline limestone (Clayey, gibbsitic, nonacid, isohyperthermic, and Lithic Ustorthents; Young, 1988). This is the primary substrate for Guam's contemporary E. joga populations. Soil at the site exhibited the following characteristics: organic matter $=$ $19.3 \%, \mathrm{pH}=7.7$, total $\mathrm{N}=9.8 \mathrm{mg} \cdot \mathrm{g}^{-1}$, MehlichIII $\mathrm{P}=163 \mu \mathrm{g} \cdot \mathrm{g}^{-1}$, Mehlich-III $\mathrm{K}=222 \mu \mathrm{g} \cdot \mathrm{g}^{-1}$, Mehlich-III magnesium $(\mathrm{Mg})=477 \mu \mathrm{g} \cdot \mathrm{g}^{-1}$, and Mehlich-III calcium $(\mathrm{Ca})=7080 \mu \mathrm{g} \cdot \mathrm{g}^{-1}$.

The plants were established in $2.6-\mathrm{L}$ containers growing in a $60 \%$ peat and $40 \%$ perlite medium. Nursery fertilization consisted of weekly application of $50 \mathrm{~mL}$ of
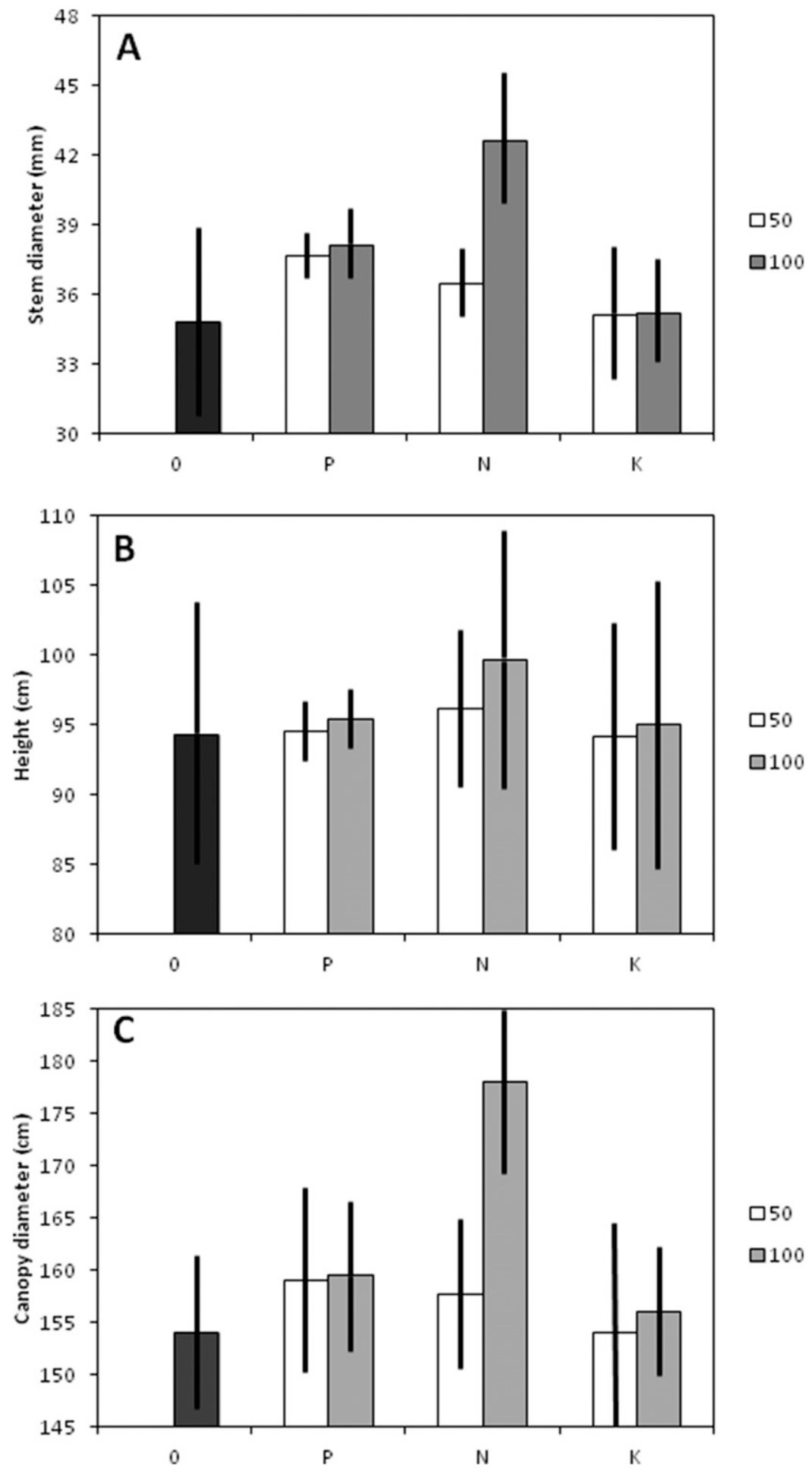

Fig. 2. Growth traits of Elaeocarpus joga plants grown in Guam cobbly clay soils as influenced by fertilization with nitrogen $(\mathrm{N})$, phosphorus $(\mathrm{P})$, or potassium $(\mathrm{K})$ to achieve 50 or $100 \mathrm{~g}$ per plant per year. (A) Increase in basal stem diameter, (B) increase in plant height, and (C) increase in canopy diameter. Mean $\pm \mathrm{SE}, \mathrm{n}=10$. complete fertilizer solution (Excel; GraceSierra, Milpitas, CA) providing $7.5 \mathrm{~mm}$ N. In addition, the plants received a monthly application of $50 \mathrm{~mL}$ of iron $(\mathrm{Fe})$ chelate (Sprint 138; Becker Underwood, Ames, IA). Our use of low-dosage frequent-soluble fertilizer applications in the nursery produced plants with minimal nutrient reserves in the container media after the plants were transplanted. 
The plants were transplanted into a $2 \times 4 \mathrm{~m}$ grid in the field on 13 Feb. 2001 when they were $85 \pm 3 \mathrm{~cm}$ tall with canopy diameter of $37 \pm 3 \mathrm{~cm}$ and basal stem diameter of $11 \pm$ $1 \mathrm{~mm}$. We used a randomized complete block design positioned on a north-south gradient. Ten single-tree replications were assigned to each prescribed treatment. One treatment consisted of control trees, which received no supplemental fertilizer. Fertilization of $\mathrm{N}$ was was performed with $\mathrm{Ca}\left(\mathrm{H}_{2} \mathrm{PO}_{4}\right)_{2}$, and fertilization of $\mathrm{K}$ was performed with $\mathrm{K}_{2} \mathrm{SO}_{4}$. There were two dose levels per fertilizer treatment. One dose provided $50 \mathrm{~g}$ of the element per tree per year, and one dose provided $100 \mathrm{~g}$ of the element per tree per year. For $\mathrm{N}$ and $\mathrm{K}$, the annual rate was split among fertilizer applications made on the day of planting and every 2 month thereafter. For P, the entire amount of fertilizer was incorporated into the planting hole and backfill on the date of planting. Each plant received irrigation every $3 \mathrm{~d}$ by way of drip emitters that delivered $7.5 \mathrm{~L}$ per plant such that each plant received $17.5 \mathrm{~L} \cdot$ week $^{-1}$.

Mature green leaf samples were collected from the control trees and the trees receiving the $100 \mathrm{~g}$ dose level for each of the nutrient addition treatments (trees in the $50 \mathrm{~g}$ dose level were not included). Samples were restricted to recently expanded and sunexposed leaves, and each tree's composite sample consisted of at least 15 leaves. These leaf samples were collected on 28 Nov. 2001, annual rainy season and a delay of 4 weeks after the most recent fertilizer applications. The samples were dried to constant weight at performed with $\mathrm{NH}_{4} \mathrm{NO}_{3}$, fertilization of $\mathrm{P}$ which enabled collection at the end of Guam's

$70{ }^{\circ} \mathrm{C}$, milled, then total $\mathrm{N}$ was determined by dry combustion (FLASH EA1112 CHN analyzer; Thermo Fisher, Waltham, MA), and $\mathrm{P}$ and $\mathrm{K}$ were determined by inductively coupled plasma optical emission spectrometry (Spectro Genesis; SPECTRO Analytical Instruments, Kleve, Germany) (Hou and Jones, 2000).

Final tree growth measurements were conducted on 4 Feb. 2002 following 1 year of growth under the experimental conditions. Terminal measurements included basal stem circumference measured with a flexible tape measure then converted to diameter, and plant height and diameter measured with a rigid tape measure.

Soils and leaves from natural habitats. Ten mature E. joga trees were visited from 3 to 11 Nov. 2014. The trees ranged in height from 8 to $14 \mathrm{~m}$, with a mean of $10 \mathrm{~m}$. They ranged in diameter at breast height from 41 to $53 \mathrm{~cm}$, with a mean of $48 \mathrm{~cm}$. For each tree, youngest fully expanded green leaves were harvested from the cardinal positions within the canopy using a telescopic pole pruner. Soil samples were composed of a composite from the surface to the solid $\mathrm{CaCO}_{3}$ contiguous base, and ranged in depth to $11-18 \mathrm{~cm}$ of soil. Samples were obtained from eight locations at the edge of the canopy. All leaves from each tree were combined into one composite tissue sample. All soil samples at each tree site were combined to create one composite soil sample. The leaves were dried at $70^{\circ} \mathrm{C}$ and milled, and analyzed as previously described with the addition of carbon (C) determined by dry combustion. The soil was dried at $50{ }^{\circ} \mathrm{C}$ then $\mathrm{C}$ and $\mathrm{N}$ were determined by dry combustion, available $\mathrm{P}$ was determined

Table 1. The influence of adding $100 \mathrm{~g}$ per tree of nitrogen $(\mathrm{N})$, phosphorus $(\mathrm{P})$, or potassium $(\mathrm{K})$ to Elaeocarpus joga plants on green leaf nutrient concentrations and stoichiometry. Fertilizer treatments were begun on 13 Feb. 2001 and leaf samples were collected on 28 Nov. 2001 (mean $\pm \mathrm{SE}, \mathrm{N}=10$ ).

\begin{tabular}{lrrrrr}
\hline Variable & \multicolumn{1}{c}{ Control } & \multicolumn{1}{c}{$\mathrm{N}$} & \multicolumn{1}{c}{$\mathrm{P}$} & $\mathrm{K}$ & $\mathrm{P}$ \\
\hline $\mathrm{N}\left(\mathrm{mg} \cdot \mathrm{g}^{-1}\right)$ & $9.50 \pm 0.76$ & $13.67 \pm 1.20$ & $12.33 \pm 1.45$ & $10.83 \pm 1.59$ & 0.1985 \\
$\mathrm{P}\left(\mathrm{mg} \cdot \mathrm{g}^{-1}\right)$ & $1.47 \pm 0.02$ & $1.55 \pm 0.12$ & $1.69 \pm 0.09$ & $1.64 \pm 0.15$ & 0.5275 \\
$\mathrm{~K}\left(\mathrm{mg} \cdot \mathrm{g}^{-1}\right)$ & $1.01 \pm 0.15$ & $1.06 \pm 0.10$ & $1.49 \pm 0.29$ & $3.63 \pm 0.93$ & 0.0159 \\
$\mathrm{~N}: \mathrm{P}$ & $6.47 \pm 0.54$ & $8.82 \pm 0.29$ & $7.23 \pm 0.46$ & $6.54 \pm 0.48$ & 0.0286 \\
$\mathrm{~N}: \mathrm{K}$ & $10.35 \pm 1.52$ & $13.25 \pm 2.40$ & $9.26 \pm 2.72$ & $3.36 \pm 0.94$ & 0.0126 \\
$\mathrm{~K}: \mathrm{P}$ & $0.65 \pm 0.10$ & $0.70 \pm 0.11$ & $0.91 \pm 0.22$ & $2.25 \pm 0.55$ & 0.0184 \\
\hline
\end{tabular}

as Olsen-P (Olsen et al., 1954), and $\mathrm{K}, \mathrm{Mg}, \mathrm{Ca}$, $\mathrm{Fe}$, manganese $(\mathrm{Mn})$, copper, and zinc were determined as extractable content by diethylene triamine pentaacetic acid digestion.

Data handling. The growth defined by tree height, canopy diameter, and basal stem diameter during the 1-year study was calculated by subtracting the initial measurement from the terminal measurement for each response variable. The $\mathrm{N}: \mathrm{P}, \mathrm{N}: \mathrm{K}$, and $\mathrm{K}: \mathrm{P}$ data were $\log$ transformed to satisfy preconditions of analysis of variance (ANOVA). Other data required no transformations. Growth and leaf nutrient variables were subjected to ANOVA within the randomized complete block design using SAS V9.2. The relationship between various pairs of response variables were determined by regression analysis using the PROC GLM statement of SAS V9.2.

\section{Results}

Fertilization study. The block effect was not significant for any of the response variables. Additions of $\mathrm{N}$ increased E. joga canopy diameter $(P=0.0372)$ and stem diameter $(P=0.0136)$, but did not affect height $(P=0.6088)$ (Fig. 2). In contrast, growth was unaffected by additions of $\mathrm{P}$ or $\mathrm{K}$. Leaf $\mathrm{N}$ concentrations and leaf $\mathrm{P}$ concentrations were unaffected by soil additions of $\mathrm{N}, \mathrm{P}$, or $\mathrm{K}$ (Table 1). In contrast, leaf $\mathrm{K}$ concentrations exhibited a 3.6-fold increase with $\mathrm{K}$ soil additions, and were relatively unaffected by $\mathrm{N}$ or $\mathrm{P}$ soil additions (Table 1). Supplemental soil nutrients generated minimal but significant influence on $\mathrm{N}$ :P. In contrast, soil nutrient supplements generated a 3.9-fold difference in $\mathrm{N}: \mathrm{K}$ and a 3.5-fold difference in K:P (Table 1).

Leaf N:P was positively related to leaf $\mathrm{N}$ $(P=0.0008)$ but was not significantly related to leaf $\mathrm{P}$ (Fig. 3), indicating that variations in $\mathrm{N}$ were controlling of $\mathrm{N}: \mathrm{P}$. A marginally significant positive relationship occurred between leaf $\mathrm{N}$ and $\mathrm{N}: \mathrm{K}(P=0.0548)$, but a strong negative relationship occurred between leaf $\mathrm{K}$ and $\mathrm{N}: \mathrm{K}(P=0.0029)$ (Fig. 4). Therefore, the variation of both elements in leaf tissue controlled the variation of $\mathrm{N}: \mathrm{K}$. Leaf K positively influenced K:P $(P<0.0001)$, but leaf $\mathrm{P}$ was unrelated to $\mathrm{K}: \mathrm{P}$ (Fig. 5),
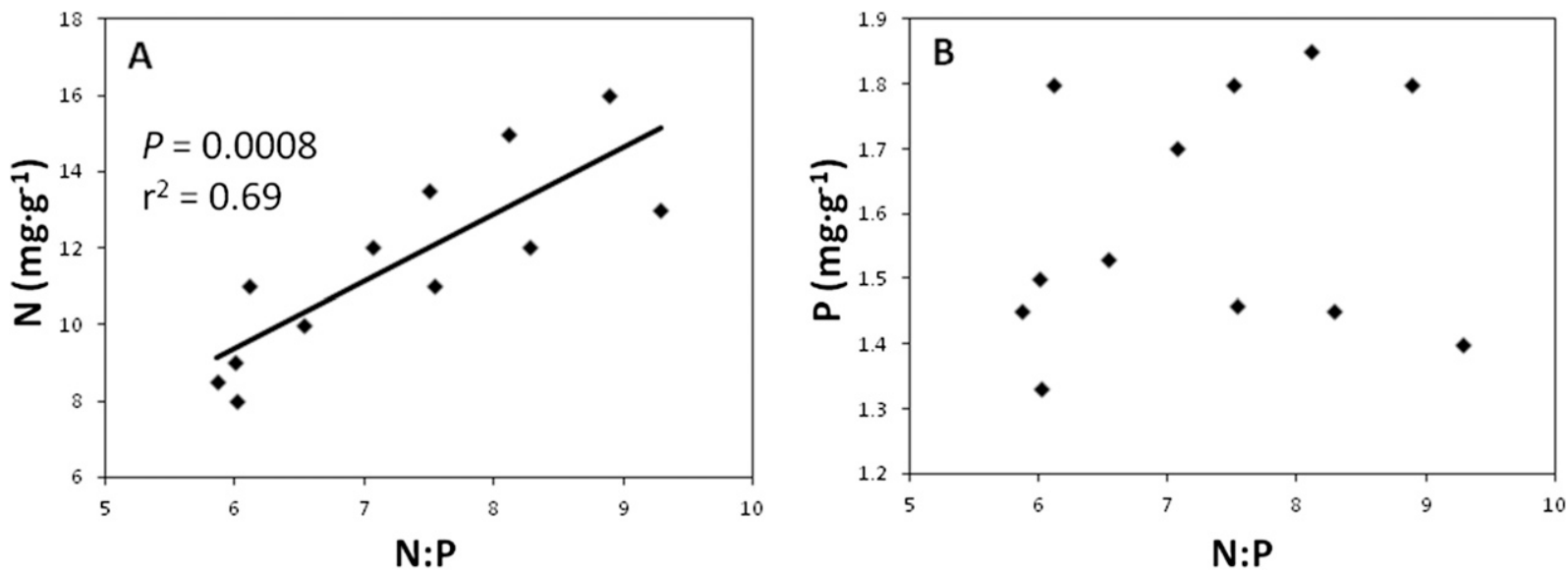

Fig. 3. Leaf (A) nitrogen or (B) phosphorus concentration as influenced by leaf N:P. 

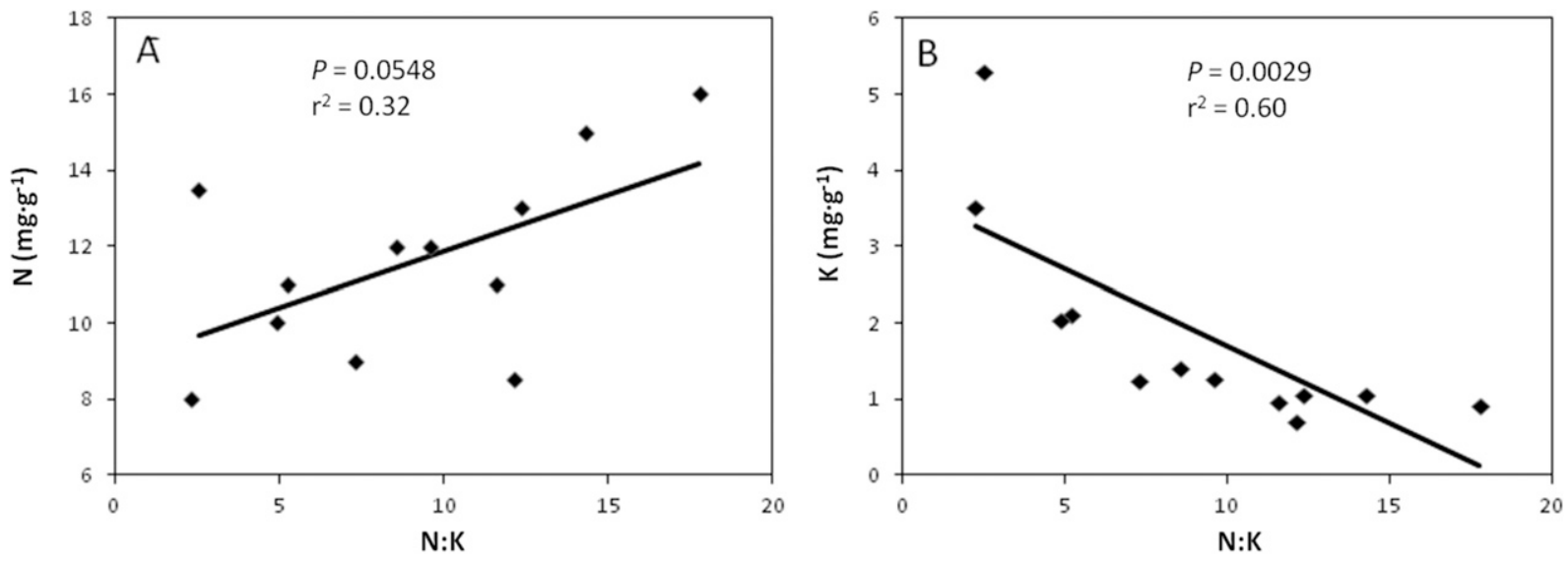

Fig. 4. Leaf (A) nitrogen or (B) potassium concentration as influenced by leaf N:K.
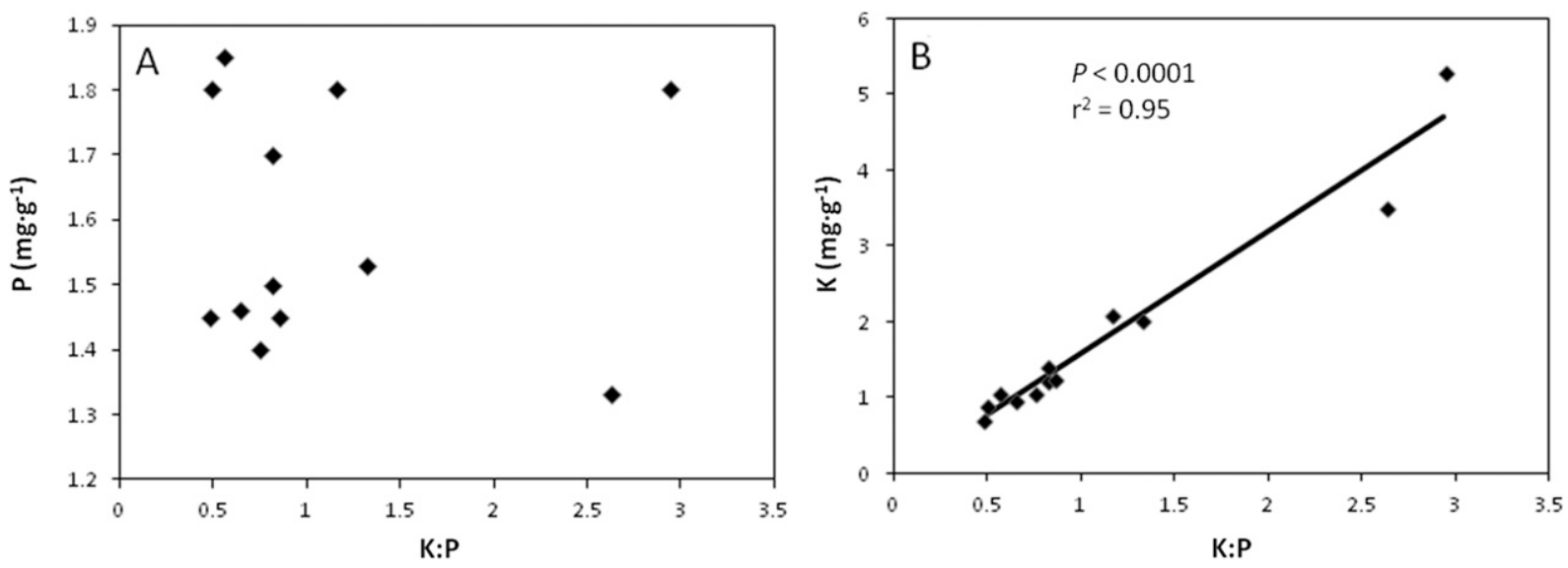

Fig. 5. Leaf (A) phosphorus or (B) potassium concentration as influenced by leaf K:P.

revealing the strong control over $\mathrm{K}: \mathrm{P}$ by leaf $\mathrm{K}$ variations.

Mature tree study. The concentrations of $\mathrm{N}$ and $\mathrm{P}$ in green leaves of $10-\mathrm{m}$-tall mature E. joga trees growing in Guam's northern limestone soils were similar to those of the control trees in our fertilization study (Tables 1 and 2). Leaf N:P was also similar between the two groups of plants. In contrast, leaf $\mathrm{K}$ of the mature trees was $\approx 50 \%$ greater than that of the small trees in our fertilization study. Soil nutrients were below those of leaf tissue for every element except $\mathrm{Mn}$, and quotients describing nutrient relations were highly contrasting to those of leaf tissue (Table 2). Soil $\mathrm{N}: \mathrm{P}$ was $\approx 10$-fold greater than leaf $\mathrm{N}: \mathrm{P}$, soil $\mathrm{N}: \mathrm{K}$ was 22 -fold greater than leaf $\mathrm{N}: \mathrm{K}$, and soil $\mathrm{K}: \mathrm{P}$ was less than that of leaf K:P. We examined the relationship of leaf stoichiometry to that of soil stoichiometry, and no clear relationship emerged for $\mathrm{N}$ : $\mathrm{P}(P=0.8019), \mathrm{N}: \mathrm{K}(P=0.5391)$, or $\mathrm{K}: \mathrm{P}(P=$ 0.8005) (Fig. 6).

\section{Discussion}

The elements most limiting to global terrestrial plant function are $\mathrm{N}$ and $\mathrm{P}$ (Chapin et al., 2002; Porder et al., 2007; Sterner and Elser, 2002; Vitousek and Howarth, 1991; Vitousek et al., 2010). Moreover, $\mathrm{K}$ is the

Table 2. Nutrient concentrations and stoichiometry (dry weight basis) of mature green Elaeocarpus joga leaves and subtending soils in northern Guam. Samples were collected in Nov. 2014 (mean \pm SE, N = 10).

\begin{tabular}{lcc}
\hline Variable & Leaves & Soil \\
\hline Carbon $\left(\mathrm{mg} \cdot \mathrm{g}^{-1}\right)$ & $480 \pm 37$ & $141.95 \pm 20.02$ \\
Nitrogen $\left(\mathrm{mg} \cdot \mathrm{g}^{-1}\right)$ & $10.23 \pm 0.51$ & $11.12 \pm 0.29$ \\
Phosphorus $\left(\mathrm{mg} \cdot \mathrm{g}^{-1}\right)$ & $1.42 \pm 0.06$ & $0.16 \pm 0.02$ \\
Potassium $\left(\mathrm{mg} \cdot \mathrm{g}^{-1}\right)$ & $1.49 \pm 0.15$ & $0.07 \pm 0.05$ \\
Magnesium $\left(\mathrm{mg} \cdot \mathrm{g}^{-1}\right)$ & $5.64 \pm 0.53$ & $0.39 \pm 0.09$ \\
Calcium $\left(\mathrm{mg} \cdot \mathrm{g}^{-1}\right)$ & $38.59 \pm 2.95$ & $11.65 \pm 3.06$ \\
Iron $\left(\mu \mathrm{g} \cdot \mathrm{g}^{-1}\right)$ & $584.42 \pm 60.97$ & $55.21 \pm 6.04$ \\
Manganese $\left(\mu \mathrm{g} \cdot \mathrm{g}^{-1}\right)$ & $116.32 \pm 12.15$ & $119.96 \pm 10.03$ \\
Copper $\left(\mu \mathrm{g} \cdot \mathrm{g}^{-1}\right)$ & $9.48 \pm 8.97$ & $3.29 \pm 0.06$ \\
Zinc $\left(\mu \mathrm{g} \cdot \mathrm{g}^{-1}\right)$ & $41.31 \pm 5.23$ & $7.27 \pm 0.81$ \\
Nitrogen:Phosphorus & $7.22 \pm 0.61$ & $69.58 \pm 38.28$ \\
Nitrogen:Potassium & $6.83 \pm 0.96$ & $151.35 \pm 12.08$ \\
Potassium:Phosphorus & $1.02 \pm 0.10$ & $0.42 \pm 0.03$ \\
\hline
\end{tabular}

second most abundant nutrient in plant leaves, and is central to understanding water relations of plants and climatic gradients (Gotelli et al., 2008; Rivas-Ubach et al., 2012; Sardans et al., 2012). Quantifying nutrient limitations of plant productivity is a fundamental task for understanding components of geochemical cycling. Using global data sets, the leaf nutrient traits for E. joga fit within what would be expected for tree species with short-lived leaves, but $\mathrm{K}$ concentrations were positioned at the extreme low end of the expected range (Wright et al., 2004, 2005). Guam cobbly clay loam is a widespread entisol on the limestone plateau of northern Guam. The series is typified by low to very low extractable $\mathrm{K}$, low activity of the clay fraction, and substantial cation exchange capacity attributed to the organic matter fraction (Carroll and Hathaway, 1963; Schlub, 2011). The contiguous limestone bedrock severely limits rooting depth, and trees that grow in this and other karst soils are characterized by exceedingly shallow roots (Nie et al., 2014). A more extensive survey of tree species in natural and urban 

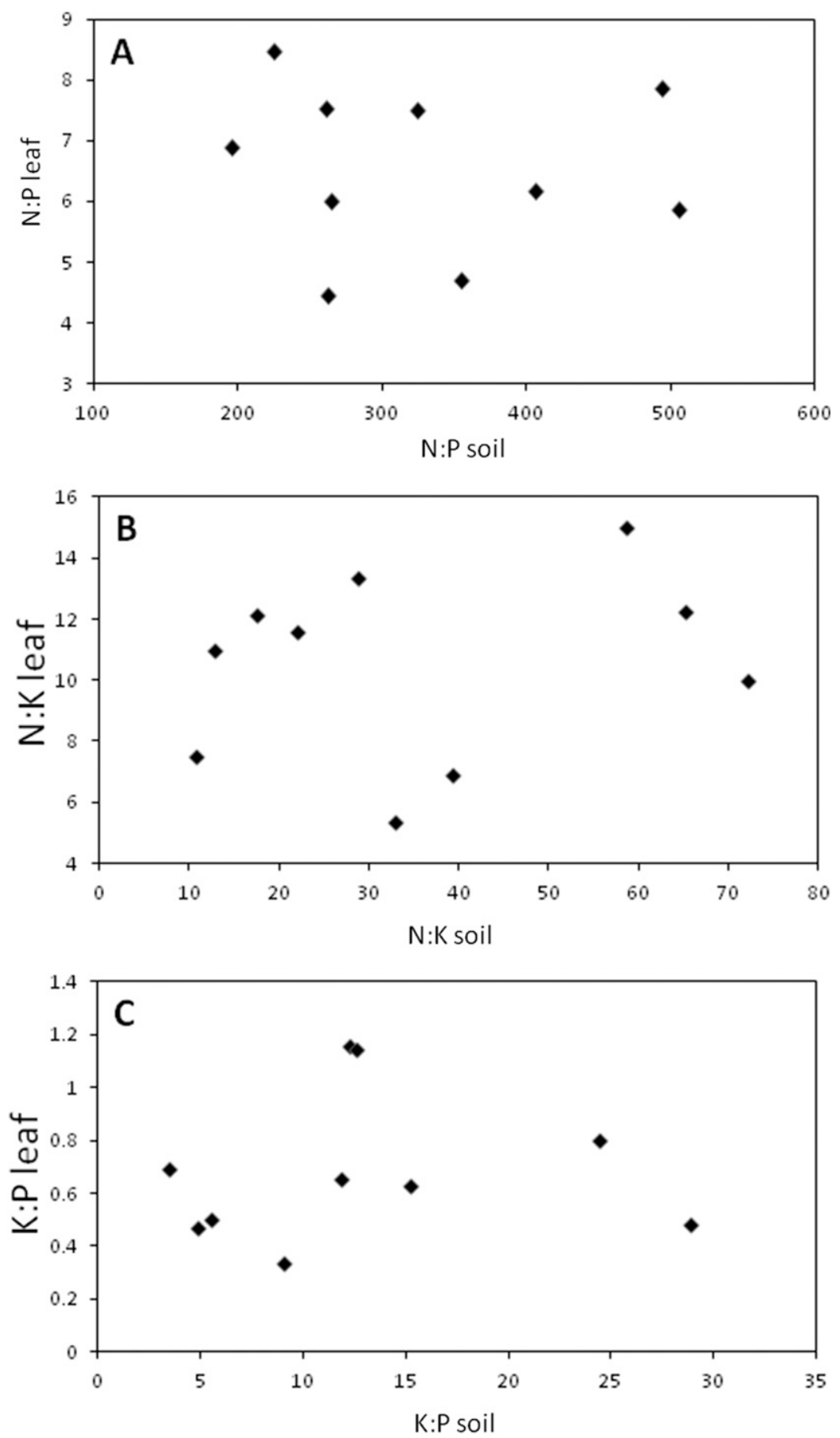

Fig. 6. The relationship between soil N:P, N:K, or K:P and green leaf (A) N:P, (B) N:K, or (C) K:P for Elaeocarpus joga trees growing in Guam's calcareous soils.

forests is needed to determine if the low leaf $\mathrm{K}$ we noted in E. joga is a widespread phenomenon for other tree species in these soils.

Growth of E. joga plants in Guam's most prevalent calcareous soil was increased with $\mathrm{N}$ additions. In contrast, $\mathrm{P}$ or $\mathrm{K}$ additions to the soil did not influence plant growth. The growth stimulation by supplemental $\mathrm{N}$ was not accompanied by a significant increase in leaf tissue $\mathrm{N}$, indicating a dilution effect whereby the stimulation of growth led to homeostasis of leaf $\mathrm{N}$ concentration. Additions of $\mathrm{P}$ also exhibited no effect on leaf $\mathrm{P}$ concentrations, but additions of $\mathrm{K}$ resulted in significant increases in leaf $\mathrm{K}$ concentration. These results indicated $\mathrm{N}$ and $\mathrm{K}$ limitations are evident for this tree, with $\mathrm{N}$ additions increasing growth without influencing leaf concentrations, and $\mathrm{K}$ additions increasing leaf concentrations without stimulating growth.

The transition in $\mathrm{N}: \mathrm{P}$ that predicts whether $\mathrm{N}$ or $\mathrm{P}$ is limiting is between 14 and 16 (Aerts and Chapin, 2000; Güsewell, 2004; Koerselman and Meuleman, 1996; Tessier and Raynal, 2003). Adding $\mathrm{N}$ or $\mathrm{P}$ to these $E$. joga trees did not appreciably alter the leaf N:P, and the 14-16 range that indicates a transition in limitation estimations was not approached for any replication. Adding $\mathrm{N}$ without adding $\mathrm{P}$ can lead to situations where $\mathrm{P}$ becomes a secondary-limiting nutrient (Agüero et al., 2014; Vitousek et al., 2010), but we did not encounter this phenomenon within our $E$. joga case study. Leaf $\mathrm{N}: \mathrm{K}$ above 2.1 or K:P below 3.4 indicates the potential for $\mathrm{K}$ limitations (Olde Venterink et al., 2003). Therefore, the behavior of $E$. joga trees in our study, including the trees that received $\mathrm{K}$ fertilizer, also signified $\mathrm{K}$ limitation in these soils.

Leaf chemical traits in small plants may differ from those in mature trees. For example, leaf $\mathrm{N}: \mathrm{P}$ of seedlings can be much lower than leaf N:P of adult trees (Diehl et al., 2003, 2008). The control plants in our fertilizer study with young trees exhibited leaf $\mathrm{N}: \mathrm{P}$ of 6.47, and the mature 10-m-tall trees in forested areas exhibited a similar leaf N:P of 7.22 (Tables 1 and 2). In contrast, the quotients that included $\mathrm{K}$ for the small control trees in our fertilizer experiment were contrasting from those for the unmanaged mature trees. $\mathrm{N}: \mathrm{K}$ for the mature trees was $66 \%$ of that for the small trees, and K:P of mature trees was 1.6-fold greater than that of the small trees, indicating acquisition and retention of $\mathrm{K}$ from these $\mathrm{K}$-limited soils may improve with tree age. Further research is warranted to determine when the ability to increase acquisition or retention of $\mathrm{K}$ begins as trees age.

With continued research to determine nutrient resorption and stoichiometry traits of other important native tree species, our results provide the foundation for the conceptual framework of determining how native tree species imprint soil traits, generate legacy effects on soils, or lead to home-field advantage for litter decomposition (Gholz et al., 2000). Although leaf stoichiometry did not covary with soil stoichiometry among replications for this single species, stoichiometry of plant organs and soils should be linked in theory (Sterner and Elser, 2002), and leaf stoichiometry has been correlated with soil stoichiometry among all species within a single habitat (Bell et al., 2014).

In conclusion, the $\mathrm{N}, \mathrm{P}$, and $\mathrm{K}$ concentrations and stoichiometry in leaves of $E$. joga represent the first look at these chemical traits in a manner that informs nutrient limitations of native tree species within the highly threatened Mariana Islands. Growth increases following $\mathrm{N}$ fertilization illuminated $\mathrm{N}$ as the main limiting nutrient for this species in this setting. Stoichiometric approaches revealed $\mathrm{N}$ and $\mathrm{K}$ limitations were not relieved by supplemental fertilizer. Increased understanding of these traits may help to assess the influence of using $E$. joga trees in the urban forest and the competitive and facilitative interactions among the vegetation components of Guam's limestone soils as anthropogenic activities continue to impose threats. Similar studies on other native tree species that are culturally valuable and exhibit horticultural appeal will provide urban resource planners with relevant local data to confront ongoing challenges (Pereira et al., 
2015). Moreover, we have added information to a data void within global databases in leaf economic spectrum studies (Donovan et al., 2011; Grime et al., 1997; Reich, 2005; Wright et al., 2004, 2005). These data from an underrepresented geographic region and underrepresented plant family will improve robustness of those global data sets for identifying the major dimensions of trait variation throughout the vegetation of the world.

\section{Literature Cited}

Aerts, R. and F.S. Chapin. 2000. The mineral nutrition of wild plants revisited: A re-evaluation of processes and patterns. Adv. Ecol. Res. 30:1-67.

Ågren, G.I. 2008. Stoichiometry and nutrition of plant growth in natural communities. Annu. Rev. Ecol. Evol. Syst. 39:153-170.

Agüero, M.L., J. Puntieri, M.J. Mazzarino, J. Grosfeld, and C. Barroetaveña. 2014. Seedling response of Nothofagus species to $\mathrm{N}$ and P: Linking plant architecture to $\mathrm{N} / \mathrm{P}$ ratio and resorption proficiency. Trees 28:1185-1195.

Bell, C., Y. Carrillo, C.M. Boot, J.D. Rocca, E. Pendall, and W.D. Wallenstein. 2014. Rhizosphere stoichiometry: Are C:N:P ratios of plants, soils, and enzymes conserved at the plant specieslevel? New Phytol. 201:505-517.

Carroll, D. and J.C. Hathaway. 1963. Mineralogy of selected soils from Guam. Geological survey professional paper 403-F. U.S. Government Printing Office, Washington, D.C.

Chapin, F.S., P.A. Matson, and H.A. Mooney. 2002. Principles of terrestrial ecosystem ecology. Springer-Verlag, New York, NY.

Craine, J.M., C. Morrow, and W.D. Stock. 2008. Nutrient concentration ratios and co-limitation in South African grasslands. New Phytol. 179:829-836.

Diehl, P., M.J. Mazzarino, F. Funes, S. Fontenla, M. Gobbi, and J. Ferrari. 2003. Nutrient conservation strategies in native Andean-Patagonian forests. J. Veg. Sci. 14:63-70.

Diehl, P., M.J. Mazzarino, and S. Fontenla. 2008. Plant limiting nutrients in Andean-Patagonian woody species: Effects of interannual rainfall variation, soil fertility and mycorrhizal infection. For. Ecol. Mgt. 255:2973-2980.

Donovan, L.A., H. Maherali, C.M. Caruso, H. Huber, and H. de Kroon. 2011. The evolution of the worldwide leaf economics spectrum. Trends Ecol. Evol. 26:88-95.

Fritts, T.H. and G.H. Rodda. 1998. The role of introduced species in the degradation of island ecosystems: A case history of Guam. Annu. Rev. Ecol. Syst. 29:113-140.

Gholz, H.L., D.A. Wedin, S.M. Smitherman, M.E. Harmon, and W.J. Parton. 2000. Long-term dynamics of pine and hardwood litter in contrasting environments: Toward a global model of decomposition. Glob. Change Biol. 6:751-765.

Gotelli, N.J., P.J. Mouser, S.P. Hudman, S.E. Morales, D.S. Ross, and A.M. Ellison. 2008. Geographic variation in nutrient availability, stoichiometry, and metal concentrations of plants and pore-water in ombrotrophic bogs in New England, USA. Wetlands 28:837-840.
Grime, J.P., K. Thompson, R. Hunt, J.G. Hodgson, J.H.C. Cornelissen, I.H. Rorison, G.A.F. Hendry, T.W. Ashenden, A.P. Askew, S.R. Band, R.E. Booth, C.C. Bossard, B.D. Campbell, J.E.L. Cooper, A.W. Davison, P.L. Gupta, W. Hall, D.W. Hand, M.A. Hannah, S.H. Hillier, D.J. Hodkinson, A. Jalili, Z. Liu, J.M.L. Mackey, N. Matthews, M.A. Mowforth, A.M. Neal, R.J. Reader, K. Reiling, W. Ross-Fraser, R.E. Spencer, F. Sutton, D.E. Tasker, P.C. Thorpe, and J. Whitehouse. 1997. Integrated screening validates primary axes of specialization in plants. Oikos 79:259-281.

Güsewell, S. 2004. N:P ratios in terrestrial plants: Variation and functional significance. New Phytol. 164:243-266.

Hou, X. and B.T. Jones. 2000. Inductively coupled plasma/optical emission spectrometry, p. 9468 9485. In: R.A. Meyers (ed.). Encyclopedia of analytical chemistry. Wiley, Chichester.

Koerselman, W. and A.F.M. Meuleman. 1996. The vegetation $\mathrm{N}: \mathrm{P}$ ratio: A new tool to detect the nature of nutrient limitation. J. Appl. Ecol. 33:1441-1450.

Lee, D.W. 1991. Ultrastructural basis and function of iridescent blue color of fruits in Elaeocarpus. Nature 349:260-262.

Marler, T.E. 2013a. Military ecology more fitting than warfare ecology. Environ. Conserv. 40:207208.

Marler, T.E. 2013b. The intersection of a military culture and indigenous peoples in conservation issues. Commun. Integr. Biol. 6:e26665 doi: 10.4161/cib.26665.

Marler, T.E. and A. Moore. 2011. Military threats to terrestrial resources not restricted to wartime: A case study from Guam. J. Environ. Sci. Eng. 5:1198-1214.

Metali, F., K.A. Salim, and D.F.R.P. Burslem. 2012. Evidence of foliar aluminium accumulation in local, regional and global datasets of wild plants. New Phytol. 193:637-649.

Nie, Y.P., H.S. Chen, K.L. Wang, and Y.L. Ding. 2014. Rooting characteristics of two widely distributed woody plant species growing in different karst habitats of southwest China. Plant Ecol. 215:1099-1109.

Olde Venterink, H., M.J. Wassen, A.W.M. Verkroost, and P.C. de Ruiter. 2003. Species richnessproductivity patterns differ between $\mathrm{N}-, \mathrm{P}-$, and K-limited wetlands. Ecology 84:2191-2199.

Olsen, S., C. Cole, F. Watanabe, and L. Dean. 1954. Estimation of available phosphorus in soils by extraction with sodium bicarbonate. USDA Circ. No. 939, U.S. Govt. Print Office, Washington, DC.

Pereira, J.A.A., A.T. de Oliveira-Filho, P.V. Eisenlohr, P.L.S. Miranda, and J.P. de Lemos Filho. 2015. Human impacts affect tree community features of 20 forest fragments of a vanishing Neotropical hotspot. Environ. Mgt. 55:296-307.

Porder, S., P.M. Vitousek, O.A. Chadwick, C.P. Chamberlain, and G.E. Hilley. 2007. Uplift, erosion, and phosphorus limitation in terrestrial ecosystems. Ecosystems 10:158-170.

Raulerson, L. and A. Rinehart. 1991. Trees and shrubs of the northern Mariana Islands. Coastal Resource Management, Commonwealth of the Northern Mariana Islands, Saipan.
Reich, P.B. 2005. Global biogeography of plant chemistry: Filling in the blanks. New Phytol. 168:263-266.

Rivas-Ubach, A., J. Sardans, M. Pérez-Trujillo, M. Estiarte, and J. Penuelas. 2012. Strong relationship between elemental stoichiometry and metabolome. Proc. Natl. Acad. Sci. 109:4181-4186.

Rodda, G.H., T.H. Fritts, and P.J. Conry. 1992. Origin and population growth of the brown tree snake, Boiga irregularis, on Guam. Pac. Sci. 46:46-57.

Rogers, H., J. HilleRis Lambers, R. Miller, and J.J. Tewksbury. 2012. 'Natural experiment' demonstrates top-down control of spiders by birds on a landscape level. PLoS One 7(9):e43446 doi: 10.1371/journal.pone.0043446.

Sardans, J., J. Penuelas, M. Coll, J. Vayreda, and A. Rivas-Ubach. 2012. Stoichiometry of potassium is largely determined by water availability and growth in Catalonian forests. Funct. Ecol. 26:1077-1089.

Schlub, R.L. 2011. Soil fertility and nutrient management for Guam and the Northern Mariana Islands. Guam Cooperative Extension Service University of Guam, Mangilao, Guam.

Seetha, K.N. 2008. Power of rudraksha. 4th ed. Jaico Publishing House, Mumbai, India.

Sterner, R.W. and J.J. Elser. 2002. Ecological stoichiometry: The biology of elements from molecules to the biosphere. Princeton University Press, Princeton, NJ.

Tessier, J.T. and D.J. Raynal. 2003. Use of nitrogen to phosphorus ratios in plant tissue as an indicator of nutrient limitation and nitrogen saturation. J. Appl. Ecol. 40:523-534.

Vitousek, P.M. and R.W. Howarth. 1991. Nitrogen limitation on land and in the sea: How can it occur? Biogeochemistry 13:87-115.

Vitousek, P.M., S. Porder, B.Z. Houlton, and O.A. Chadwick. 2010. Terrestrial phosphorus limitation: Mechanisms, implications, and nitrogenphosphorus interactions. Ecol. Appl. 20:5-15.

von Wirén, N. 2011. Grand challenges in plant nutrition. Front. Plant Sci. 2:4 doi: 10.3389/ fpls.2011.00004.

Wiles, G.J. 2005. Decline of a population of wild seeded breadfruit (Artocarpus mariannensis) on Guam, Mariana Islands. Pac. Sci. 59:509522 .

Wright, I.J., P.B. Reich, J.H.C. Cornelissen, D.S Falster, E. Garnier, K. Hikosaka, B.B. Lamont, W. Lee, J. Oleksyn, N. Osada, H. Poorter, R. Villar, D.I. Warton, and M. Westoby. 2005. Assessing the generality of global leaf trait relationships. New Phytol. 166:485-496.

Wright, I.J., P.B. Reich, M. Westoby, D.D. Ackerly, Z. Baruch, F. Bongers, J. Cavender-Bares, T. Chapin, J.H. Cornelissen, M. Diemer, J. Flexas, E. Garnier, P.K. Groom, J. Gulias, K. Hikosaka, B.B. Lamont, T. Lee, W. Lee, C. Lusk, J.J. Midgley, M.L. Navas, U. Niinemets, J. Oleksyn, N. Osada, H. Poorter, P. Poot, L. Prior, V.I. Pyankov, C. Roumet, S.C. Thomas, M.G. Tjoelker, E.J. Veneklaas, and R. Villar. 2004. The worldwide leaf economics spectrum. Nature 428:821-827.

Young, F.J. 1988. Soil survey of Territory of Guam. United States Dept. Agr. Soil Conservation Service. 